\title{
Evaluation of the Present Information on the Mechanisms Leading to Flower Bud Induction, Evocation and Differentiation in Olea europaea.
}

\author{
A. Troncoso ${ }^{1}$, J.L. Garcia ${ }^{1}$ and S. Lavee ${ }^{2}$ \\ ${ }^{1}$ Instituto de Recursos Naturales y Agrobiología (CSIC) Sevilla, Spain. \\ ${ }^{2}$ Institutes of Plant Science, Faculty of Agriculture (HUJ) and the Volcani Center, Israel.
}

Keywords: Olea europaea, Manzanillo, bud differentiation, flower induction.

\begin{abstract}
The lack of regularity in reproductive organ development leading in many cases to severe alternate bearing is one of the major problems and drawbacks in today's economy of the olive industry. Although a considerable amount of work has been devoted during the second half of the last century to this subject, our understanding of the metabolism leading to flower bud differentiation and ability to control alternate bearing is still limited. The genetic potential to induce flower buds is environmentally dependent. Temperature was found the most eminent environmental factor to affect the metabolism leading to flower bud induction. Specific but not yet clearly defined temperatures in early summer on one hand and relatively low winter temperature gradually fluctuating with warm ones in the winter are essential for inducing the metabolic pass-ways initiating the sequence of processes leading to the formation of flower buds. Changes in the RNA content of lateral buds expected to develop inflorescences in the spring was shown to occur already in the fall. Thus, some workers suggested that the low winter temperatures act as a dormancy breaking agent of pre differentiated buds. On the other hand, these same buds were shown to grow vegetative when induced without or with unsuitable winter temperature. This could be explained as dedifferentiation process however, no differentiated floral organs have been found in buds in the fall and no aborted secondary growing points in lateral buds have been found either. The presently available data indicate that neither summerfall nor mid winter seasons could be individually responsible for flower bud initiation. The presently developing fruits on the trees were found to have a major affect on controlling the metabolism leading to reproductive development although they were shown to have no effect on the tree's carboydrate level and only a minor one on the nitrogen balance. However, the protein composition of leaves on fruiting and non fruiting trees was found to be different with specific proteins developing in leaves of the fruiting trees and others on the non fruiting ones. Furthermore, chlorogenic acid, related to the cinnamic acid pass-way was found to accumulate in leaves of fruiting trees and to inhibit specifically winter differentiation. The messenger from the developing fruits to change the leaf metabolism is not yet entirely clear but believed to be specific gibberellins. Based on the present available data including the effect of harvest time on the following reproductive development and the amount of yield on vegetative growth, a two phase mechanism for reproductive bud development in the olive could be suggested. The initial developing bud of the olive is suggested to be indifferent. During the "off" year, when tha plant has normalized its situation after a heavy crop, the buds receive their initial induction to develop reproductive. Those buds which received their initial induction to differentiate reproductively will respond to the winter inductive conditions.
\end{abstract}




\section{INTRODUCTION}

The lack of regularity in reproductive organ development leading in many cases to severe alternate bearing is one of the major economical drawbacks of today's olive industry. Although a considerable amount of work has been devoted during the second half of the last century to this problem, our understanding of the metabolism involved and ability to control alternate bearing is still limited. The potential to induce flower bud formation is governed both by the endogenous metabolic processes and the environment, mainly the thermal conditions. It is presently quite clear that both the late spring and winter temperatures play a significant role in controlling the differentiation of reproductive buds. However, neither the required summer nor the low winter temperature regimes are clearly defined. Even the nature of the responses to temperature is still disputed among the various workers in the field. Laboratory experiments with cuttings indicated that lateral bud can develop vegetatively or reproductively according to the thermal conditions during fall and winter. Thus, the genetic potential to initiate flower bud induction and differentiation on developing shoots is environmentally dependent. Reproductive buds were reported to show some changes in their RNA already at the end of the summer, however, these buds will develop reproductively only if suitable winter conditions will prevail. The present available data indicate that neither summer-fall nor mid winter seasons could individually be responsible for flower bud initiation. The developing fruits on the tree have a major effect on controlling shoot growth as well as the metabolism leading to reproductive development in the buds. The protein composition in leaves of fruiting and non-fruiting trees differs, with specific ones developing in the leaves of each group (Lavee and Avidan, 1994). Furthermore, a conjugated polyphenol, chlorogenic acid, related to the cinnamic acid pass-way is accumulating in leaves of fruiting trees and specifically inhibits the winter differentiation of the buds (Lavee, 1989). The messenger from the developing fruits to change the leave's metabolism is believed to be a specific gibberellin. While harvest time is effecting bud differentiation, fruit load has in addition also a major effect on shoot growth. The lack of shoot growth on a heavily fruit bearing olive tree is directly related to fruiting alternation as no potential buds for differentiation are developing. This lack of growth occurs although the level of carbohydrates in the leaves was found similar in 'on' and 'off' years. The aim of this work was to study the mineral situation of the olive tree and its fluctuation during and after a high production year, in relation to shoot growth, new lateral bud development, and some biochemical compounds levels and their influence on the following crop formation.

\section{MATERIAL AND METHODS}

The study was conducted over a period of three years (two "on" and one "off”) on ten 20 year old cv Manzanillo olive trees, growing in the "Aljarafe” zone (Seville, Spain). The number of inflorescences/infrutescences, flowers and later fruits, fruit weight, terminal growth of the reproductive shoots and. the total fruit yield at harvest was recorded on a monthly basis.

Samples of leaves and buds were taken for analysis from each tree at the same monthly intervals. The leaves were analyzed for their mineral nutrients ( $\mathrm{N}, \mathrm{P}, \mathrm{K}, \mathrm{Ca}, \mathrm{Mg}$, Fe, Mn and B) as described elsewhere (García et al., 1999). The buds were fixed in FAA and prepared for observation under an optical microscope according to Troncoso (1967). The general situation of the trees was described at each sampling date. 


\section{RESULTS AND DISCUSSION}

\section{Plant situation after a heavy crop year}

In a high 'on' year almost all the buds on the shoots grown in the previous year developed into inflorescences, except for those on the very short terminal parts of the branches which usually remain vegetative. As our study was carried out on cV Manzanillo, a table olive variety, the plants were already without fruits in the fall. Still, all the buds of recent formation except for the apical one were poorly developed.

Depending on the time of harvest, in an 'on' year the olive tree enters the winter chilling period (decisive period for bud differentiation) with or without fruits. In both cases, there was a negative influence for the crop of the following year. The productive branches of the present year which comprise the majority of a productive tree have no visible axillary buds left after the heavy cropping on the shoots. Only on the apical part of the branch where some limited growth might occur even during the period of fruit development viable buds can be found. This growth however, consisted of short $(9 \mathrm{~cm}$ long) semiherbaceous twigs with still developing young leaves and axillary buds and an apical bud responsible of the twig elongation. The leaves at the basal and medium zones of the twigs now two years old, are showing symptoms of ageing and some are falling.

The leave nutrient contents in the winter of a crop year show very low levels of $\mathrm{N}$, $\mathrm{P}$ and $\mathrm{K}$ and high accumulation of $\mathrm{Ca}$ (Table 1). This results in a nutritive imbalance, particularly in relation to $\mathrm{Ca} / \mathrm{K}$ and $\mathrm{N} / \mathrm{K}$ ratios, as compared to the optimum levels defined by González-García et al. (1972). These data according to Mengel and Kirby (1982) indicate low activity, cell senescence and represent a negative factor for the development of a new crop

The crop provokes profound alterations in the metabolism of the tree. GonzálezGarcía et al. (1976) found that the general content of phenolic acids at the end of an 'on' year was low and linked to low IAA oxidase activity and a marked drop of tryptophane, converted into IAA. This situation is reversed in the winter of 'off' years. They concluded that the less enzyme activity results in high levels of IAA which is involved in the initiation of vegetative growth of the trees (González-García et al., 1976; Catalina et al., 1978; González-García and Catalina, 1982). Lavee \& Avidan (1994) found low levels of a particular phenolic acid, CHA (chlorogenic acid), after a non productive season in contrast with a high content of CHA after a high crop year. They also showed that CHA inhibits bud differentiation when injected in the tree, concluding that $\mathrm{CHA}$ is associated to alternate bearing.

Carbohydrate metabolism is also affected by the crop and at fall the leaf contents of starch and sugars have been depleted as a consequence of the translocation of carbohydrates for the fruit growth (Sarmiento et al., 1976). This however was not confirmed by Stutte and Martin (1986) who did not find a relation between the carbohydrate content of the tree in 'on' and 'off' years.

During the short time between harvest (when carried out at fall) and winter chilling, many leaves and pedicels fall from the basal and medium branch zones, axillary wounds heal and new buds are formed, some of which sprout into new shoots with one or two pairs of small leaves. These buds however, do not differentiate, normally, during the following winter induction. A longitudinal section of these buds show a scarce development with only 1-2 pairs of bracteoles and a very small apex.

At this point the plants show vegetation deficit with small and herbaceous twigs and scarce number of young leaves photosynthetically active. 
Since winter arrives shortly after harvest and some times even before that, the trees after a high crop have no real possibility of produce new branches with buds or buds capable of being reproductive for the next season.

Then, after a heavy crop the olive plant remains in unfavourable conditions to produce due to: high vegetation deficit that the plant tries to overcome; very poor shoot growth that means lack of young shoots and leaves and consequently deficit of photosynthesis; lack of buds capable of becoming reproductive; bad nutritive equilibrium and abnormal biochemical conditions and finally lack of time between harvest and winter chilling for the initiation of new growth. All these factors arrest the formation of a new crop and the plant uses the following period to attain better conditions to produce again.

Flowering seems to be tightly related to the presence of fruits in the previous season (Rallo et al., 1994). Nevertheless, in situations where the crop is not very heavy or when a chemical clearance of fruits have been made at early stages of fruit set, the return bloom in the next spring can be rather high (Troncoso et al., 1978). Under such conditions the inhibition of flowering by the precedent crop seems to be limited. New vegetative growth with normal buds is developing on trees with a medium crop allowing for enough buds with a differentiation potential in the next spring.

\section{Recovery period ('off' year)}

As stated above, the heavily fruiting trees need to recover a vegetative, biochemical and nutritive equilibria in order to produce again. At the end of winter chilling after an 'on' year, few or no buds have formed inflorescences and the majority of them remain indifferent. The apical buds and some of the laterals which remained from the 'on' year give raise to new rapidly growing shoots as described by Troncoso et al. (1981), forming normal new shoots and leaves. Due to the apical dominance of the olive, the axillary buds on the new shoots grow slowly, increasing in size do not open to form new shoots and leaves. These two types of developments take place along the whole year, according to the seasonal climatic and tree conditions and lead to the vegetative equilibrium of the plant and the formation of the lateral buds capable of differentiate to inflorescences the next spring. Thus, the 'off' year can be considered a vegetation recovery period and bud preparation for the next crop.

During the off year the nutrient contents regain its optimal values (Table 1), while bound phenolics and N protein reach high contents at summer (Catalina et al., 1972; González-García et al., 1976; Sarmiento et al., 1977).

When winter arrived there was a difference in the development among basal and medium branch buds which were older and thicker and the very small new buds formed at terminal parts. These last were morphologically similar to those described in the apical part of productive branches although under specific growing conditions leading to early lignification of the terminal shoot parts, even these buds can be reproductive (Figure 1). With the plant again in a favourable vegetative and nutritive state, the winter inductive conditions should be the final stimulus for the buds to differentiate and develop reproductively in the following spring.

\section{Productive season ('on' year)}

While the timing and conditions of flower bud induction are not yet entirely clear, anatomical studies establish the period of flower bud differentiation around February when bud structure start to show floral primordia (see review by Fabbri and Benelli, 2000). 
González-García et al. (1976) found at this time a dramatic increase of phenolic contents associated to high IAA oxidase activity. These authors hypothesised that $\mathrm{K}$ would have a positive effect on flowering as it enhances amino acid formation which in turn stimulates IAA oxidase formation. The enzyme-mediated destruction of IAA would inhibit vegetative growth.

At spring, most buds changed morphology while differentiating to inflorescence. Only the apical bud remained vegetative though sometimes even that forms an inflorescence. The reproductive bud differentiation occurs simultaneously on the more developed lateral buds of basal and medium shoot zones and the younger buds on the terminal parts.

Usually, olive produces huge quantities of flowers but only 1-3\% of them set fruit. This means a large waste of nutrient resources which no doubt affect significantly the physiology of the tree. Thus, the nutritional input required for the reproductive stage of the olive tree demands a period for recovering its basic nutritional equilibrium before the intensive flowering period.

Out of the total formed flowers, approximately $75 \%$ fell during the period of flower maturation, anthesis and pollination while $23 \%$ of the flowers set fruits... However $90 \%$ of these fruits (21\% of the total flowers formed) abscised during the initial period of fruit development leaving only $10 \%$ of them intact (or $2.3 \%$ of the total flowers). After the initial fruit drop until harvest only $2.2 \%$ of fruits were lost, resulting in a mean harvest of $54.3 \mathrm{Kg}$ per tree with a mean fruit weight of $2.65 \mathrm{~g}$. This means that only a $2 \%$ of the initial flowers formed were collected as fruits (Table 2). On the other hand all the buds which developed inflorescences are lost for further reproductive as well as immediate vegetative development.

\section{CONCLUSIONS}

Environmental factors such as suitable light and thermal conditions are essential for the reproductive development of olive buds. However, the tree and its buds have to be in a suitable responsive physiological state in order to respond to the favourable environmental conditions. Furthermore sufficient well developed buds from the previous season with a good nutritive balance, capable to differentiate are required on the tree. After a heavy crop with very limited vegetative growth, the olive tree enters the winter with a small number of sufficient developed buds. Thus, a following growing season is required to regain a good nutrient balance for generating adequate vegetative growth with sufficient buds responsive to environmental differentiation stimuli. Only the reestablishment of healthy vegetative growth with well developed new buds can ensure a potential good crop in the year to follow.

\section{References}

Catalina L., Sarmiento R., González-García F. and Valpuesta V. 1978. El metabolismo nitrogenado en árboles de Olea europaea var. Manzanillo, en relación con la floración (II). An. Edaf. Agrob., 37(3-4): 249-257.

Catalina L., Sarmiento R. and Valpuesta V. 1972. Actividad de la indolacético-oxidasa en hojas y yemas de Olea europaea L. durante el periodo primaveral. An. Edaf. Agrob., 31(7-8):607-613.

Fabbri A. and Benelli C. 2000. Flower bud induction and differentiation in olive. J. Hortic Sci. \& Biotech., 75(2):131-141. 
García J.L., Liñán J., Sarmiento R. and Troncoso A. 1999. Effect of different N forms and concentrations on olive seedlings growth. Acta Hortic., 474:323-327.

González-García F. and Catalina L. 1982. Importancia de los factores nutricionales en la floración y fructificación del olivar. An. Edaf. Agrob., 41:959-972.

González-García F., Catalina L. and Sarmiento R. 1976. Aspectos bioquímicos de la floración de olivo variedad "Manzanillo" en relación con factores nutricionales. Comptes Rendus 4éme Colloque International "Controle de l'alimentation des plantes cultivées, Gent, 2:409-426.

González-García F., Chaves M., Mazuelos C., Troncoso A., Catalina L. and Sarmiento R. 1972. Aspectos fisiológicos en la nutrición del olivar de mesa, variedad "Manzanillo" de Sevilla. Ciclo y metabolismo de nutrientes. 3rd Colloquium European and Mediterranean on Control of Nutrition in Cultivated Plants, Budapest.

Lavee S. 1989. Involvement of plant growth regulators and endogenous growth substances in the control of alternate bearing. Acta Hortic., 239:311-322.

Lavee S. And Avidan N. 1994. Protein content and composition of leaves and shoot bark in relation to alternate bearing of olive trees (Olea europaea L.). Acta Hortic., 356:143-147.

Mengel K. and Kirkby E.A. 1982. Principles of Plant Nutrition. International Potash Institute, Worblaufen-Berna.

Rallo L., Torreño P., Vargas A. and Alvarado J. 1994. Dormancy and alternate bearing in olive. Acta Hortic., 356:127-136.

Sarmiento R., Catalina L. Valpuesta V., and González-García F.1977. El metabolismo nitrogenado en árboles de Olea europaea var. Manzanillo, en relación con la floración (I). An. Edaf. Agrob., 36: 58-63.

Sarmiento R., Valpuesta V., Catalina L. and González-García F.1976. Variación de los contenidos de almidón y carbohidratos solubles en hojas y yemas de árboles de Olea europea var. Manzanillo en relación con los procesos vegetativo y productivo. An. Edaf. Agrob., 35(7-8):687-695.

Troncoso A., Cantos M., Prieto J. and Liñán J. 1981. Influencia de la temperatura en el ciclo de producción del olivo. VII Simposio de Bioclimatología, pp. 365-374.

Troncoso A., Prieto J. and Liñán J. 1978. Aclareo químico de frutos en el olivar Manzanillo de Sevilla. An. Edaf. Agrob., 37(9-10):881-893.

Stutte G.W. and Martin G.C. 1986. Effect of light intensity and carbohydrate reserves on flowering in olive. J. Am. Soc. Hort. Sci., 111(1):27-31. 
Table 1. MIneral content in leaves at different phases of the production cycle.

\begin{tabular}{|c|c|c|c|c|c|c|c|c|c|}
\hline \multirow{2}{*}{\multicolumn{2}{|c|}{ Biannual cycle phase }} & \multicolumn{5}{|c|}{ \% d.w. } & \multicolumn{3}{|c|}{ ppm } \\
\hline & & $\mathrm{N}$ & $\mathrm{P}$ & $\mathrm{K}$ & $\mathrm{Ca}$ & $\mathrm{Mg}$ & $\mathrm{Fe}$ & $\mathrm{Mn}$ & $\mathrm{B}$ \\
\hline \multicolumn{2}{|c|}{ Winter stop after harvest } & 1.45 & 0.07 & 0.50 & 2.10 & 0.14 & 70 & 27 & 12 \\
\hline \multirow{3}{*}{$\begin{array}{l}\text { Recovery after } \\
\text { harvest } \\
\text { ('off' year) }\end{array}$} & Spring & 1.67 & 0.10 & 0.60 & 1.70 & 0.15 & 40 & 24 & 13 \\
\hline & Summer & 1.65 & 0.12 & 1.00 & 1.20 & 0.10 & 35 & 22 & 25 \\
\hline & Autumn & 1.67 & 0.13 & 0.90 & 1.20 & 0.13 & 50 & 20 & 18 \\
\hline \multicolumn{2}{|c|}{ Winter stop before harvest } & 1.75 & 0.12 & 0.80 & 1.30 & 0.13 & 50 & 20 & 14 \\
\hline \multirow{3}{*}{$\begin{array}{l}\text { Fruit } \\
\text { development } \\
\text { ('on'year) }\end{array}$} & Spring & 1.64 & 0.09 & 0.60 & 1.30 & 0.12 & 55 & 23 & 14 \\
\hline & Summer & 1.56 & 0.08 & 0.50 & 1.60 & 0.13 & 65 & 30 & 20 \\
\hline & Autumn & 1.40 & 0.06 & 0.40 & 2.20 & 0.14 & 70 & 30 & 14 \\
\hline
\end{tabular}

\begin{tabular}{|l|l|l|l|l|l|l|l|l|}
\hline Optimal Nutritional Level & 1.95 & 0.11 & 0.86 & 1.42 & 0.20 & 39 & 50 & 15 \\
\hline
\end{tabular}

Table 2. Average number of reproductive organs per tree in a high production year.

\begin{tabular}{|c|c|c|c|c|c|c|c|c|}
\hline \multirow{2}{*}{$\begin{array}{c}\mathrm{N}^{\circ} \text { of organs per } \\
\text { tree }\end{array}$} & \multicolumn{8}{|l|}{ Date } \\
\hline & March & April & May & June & July & Aug & Sept & Oct \\
\hline Productive shoots & 3610 & 3610 & 3610 & 3610 & 3610 & 3610 & 3610 & 3610 \\
\hline Reproductive buds & 69986 & & & & & & & \\
\hline Inflores./Infrutes. & & 63538 & 56695 & 33882 & 17692 & 17444 & 17444 & 17322 \\
\hline Flowers & & 1023570 & & & & & & \\
\hline Fruits & & & 239681 & 23100 & 21700 & 20600 & 20600 & 20600 \\
\hline g/fruit & & & 0.03 & 0.36 & 0.53 & 1.57 & 1.78 & 2.65 \\
\hline Kg/tree & & & & & & & & 54.3 \\
\hline Shoot growth (cm) & & 2 & 5 & 6 & 6 & 8 & 8 & 9 \\
\hline
\end{tabular}

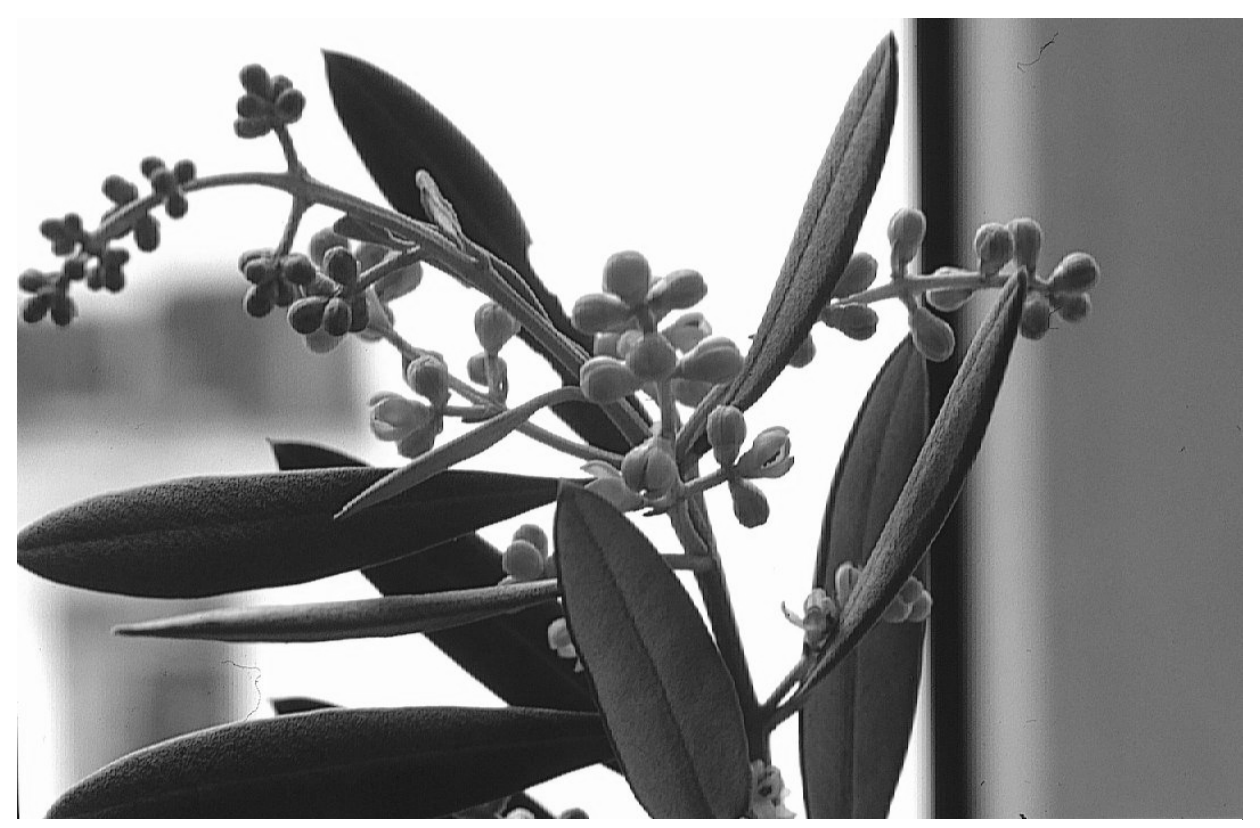

Figure 1. Inflorescence development from an olive terminal bud. 